\title{
PERILAKU PEMILIH DALAM POLLING REKTOR UNIVERSITAS PGRI ADI BUANA SURABAYA TAHUN 2015
}

\author{
Suyono \\ Prodi PPKn Universitas PGRI Adi Buana Surabaya \\ suyono.ppkn@unipasby.ac.id \\ Suhartono \\ Prodi PPKn Universitas PGRI Adi Buana Surabaya \\ suhartono@unipasby.ac.id
}

\begin{abstract}
Abstrak
Hal menarik dari fenomena politik ini adalah tidak semua orang civitas akademik UNIPA Surabaya dalam melakukan Polling Rektor UNIPA Surabaya tidak sepenuhnya hadir, masih bersifat ogah-ogahan, acuh tak acuh, tidak memperdulikan, tidak suatu hal yang luar biasa dan menarik, banyak menghabiskan waktu ditempat kerja, kegiatan semacam ini dianggap sebagai kegiatan rutin empat tahun sekali, mau memberikan suara hanya menjalankan kewajiban sebagai gugur wajib. Tujuan penelitian ini adalah 1) Memberikan penjelasan tentang citra masing-masing kandidat terhadap perilaku pemilih pada Polling Rektor UNIPA Surabaya. 2) Mendeskripsikan efektivitas Visi dan Misi masing-masing kandidat terhadap perilaku pemilih pada Polling Rektor UNIPA Surabaya. 3) Mendeskripsikan pesan yang disampaikan masing-masing kandidat perihal menyentuh akar permasalahan terhadap perilaku pemilih pada Polling Rektor UNIPA Surabaya Tahun 2015. Adapun target dari peneliti berupa jurnal yang ber-ISSN yang dipublikasikan dalam Jurnal Buana Pendidikan yang diterbitkan FKIP Univ. PGRI Adi Buana Surabaya Pada penelitian ini pendekatan yang dilakukan adalah pendekatan metode kualitatif interaksi simbolis, semua perilaku manusia pada dasarnya memiliki sosial meamings ( makna-makna sosial). Data yang akan dikumpulkan dalam penelitian ini adalah data yang sesuai dengan fokus penelitian, yang terdiri dari data primer dan data sekunder. Data primer diperoleh dalam bentuk verbal (kata-kata dan perilaku dari subjek penelitian yang berkaitan dengan fokus penelitian). Sedangkan data sekunder bersumber dari dokumen, foto, dan benda-benda yang digunakan sebagai pelengkap data primer. Analisis yang digunakan adalah ada tiga tahapan yang akan dilakukan dalam menganalisis data dalam penelitian, yaitu reduksi data, penyajian data, dan penarikan kesimpulan/verifikasi menyentuh permasalahan yang disampaikan masing-masing kandidat dalam Polling
\end{abstract}

Kata kunci: Perilaku Pemilih, Polling, Rektor

\section{PENDAHULUAN}

Suatu hal yang sangat menarik pada massa sekarang adalah Polling, selain menyajikan hal-hal yang terkini, juga mengungkapkan masalah baru yang relative cepat dan up to date, informasinya pun lewat media elektronik maupun media cetak, baik 
radio, Televisi, Surat Kabar baik cetak maupun digital, Majalah, tabloid maupun web-web internet.

Sekarang menjadi kebutuhan masyarakat akan Polling, fenomena yang menjadi ideola masyarakat karena mampu menyajikan pendapat masyarakat umum dalam waktu yang relatif pendek dan mampu menerobos ruang-ruang pribadi serta memberikan rasa nyaman bagi orang yang menyampaikan gagasannya.

Polling banyak dimanfaatkan untuk kalangan bisnis mengetahui peminat produk-produk tertentu, untuk melihat peminat pemirsa TV yang menyukai film-film tertentu, dan juga untuk mengetahui tingkat kepuasan konsumen terhadap penggunaan pelayanan, dan juga dimanfaatkan untuk mengetahui readting calon legislative pada daerah pilihan tertentu pada pemilihnya.

Penelitian tersebut penting untuk dilaksanakan untuk mengetahui sejauh mana pelaksanaan polling apa sudah sesuai dengan tujuan dari polling itu sendiri. Karena masih banyak kalangan pemilih yang belum menggunakan hak pilihannya untuk mendatangi tempat untuk menyalurkan aspirasinya, masih ogahogahan, masih ngobrol, masih bicara sendiri bersama kelompoknya dan masih sibuk kerja sendiri belum bersemangat untuk datang ke tempat penyaluran aspirasi dalam hari, tanggal dan tempat yang telah ditentukan oleh panitia. Polling (jajak pendapat) di lingkungan akademis akan dapat menjadi alternative pilihan, asal prosedur polling berpatokan pada prinsip-prinsip ilmiah.

Menurut pendapat Marlino dalam kacung Marijan (2012:109) demokrasi yang baik itu tidak hanya berkaitan dengan prosedur da isi (procedure and content) melainkan juga berkaitan dengan dengan hasil (result) dari prosedur da isi dari demokrasi itu. Menurut pendapat Hertz dalam Sukarna (1979:37) demokrasi adalah semacam pemerintahan dimana tidak ada seorang anggota masyarakat atau kelompok pun yang mempunyai hak prerogratif politik (hak yang tidak boleh diganggu gugat oleh siapa pun juga) atas orang lain. Selain polling yang baik begitu juga dengan demokrasi yang baik dan bagus tidak hanya procedure dan isi melainkan tidak kalah pentingnya adalah hasil. Sedangkan menurut Rafael (2013:201) demokrasi adalah bentuk pemerintahan dimana hak-hak untuk membuat keputusan-keputusan politik digunakan secara langsung oleh setiap warga Negara, yang di aktualisasi melalui prosedur pemerintahan mayoritas. Maksudnya masyarakat dalam menangani berbagai masalah bertemu dalam suatu ruangan, dibahas bersama dan diputuskan melalui musyawarah dengan suara terbanyak. 
Polling untuk menampung pendapat masyarakat umum memang banyak menghiasi wajah baik media cetak maupun elektronik. Mulai dari polling mengenai produk sebuah barang dan jasa, pemilihan Walikota, Kepala Daerah, Rektor dan presiden. Walaupun masih tanda Tanya dari hasil polling tersebut diatas, tepat dan tidaknya polling baik makanan atau minuman yang hanya berlalu begitu saja, bahkan banyak orang yang tidak peduli dengan hasil polling, polling memunculkan angka dan dahulu banyak yang tidak percaya dari hasil polling yang tidak mempunyai makna.

Di Universitas PGRI Adi Buana Surabaya dilaksanakan Polling calon Rektor, periode tahun 2015 sampai dengan 2019, yang telah dilaksanakan pada hari Selasa tanggal 15 September 2015, pukul 08.00 s.d. 14.00 di dua lokasi, lokasi pertama di Lobby Gedung Sarmidi Kampus Ngagel Dadi dan lokasi kedua Ruang Humas Gedung Anwar Yasin Kampus Menanggal. Dalam penyaringan, mengerucut 3 nama yang yang memenuhi syarat dan bersedia mencalonkan/dicalonkan dari 12 orang nama nominator bakal calon Rektor sampai batas akhir pengumpulan hari Selasa 8 September 2015 pukul 13.00 WIB, adapun 3 orang nama tersebut, sebagai berikut 1) Drs. Djoko Adi Walujo, DBA Jabatan Lektor Kepala, Program Studi Teknik Lingkungan, 2) Prof. Dr. Hartanto
Sunardi, M.Pd, Guru Besar Program Studi Pendidikan Matematika, 3) Prof. Dr. Gempur Santoso, M.Kes, Guru Besar Program Studi Teknik Industri. Pelaksanaan polling rektor pada hari selasa tanggal 15 September 2015, yang diikuti peserta Polling meliputi : pendiri, pengurus/anggota Badan penyelenggara, Dosen, Tenaga Kependidikan, Mahasiswa ( Ketua + Wakil Ketua SEMA-F, Ketua + Wakil Ketua Himaprodi, Ketua UKM), dari perhitungan jumlah suara diperoleh hasil Polling bakal calon Rektor sebagai berikut : 1) Djoko Adi Walujo, Drs. ST, MM, DBA 461 suara, 2) Hartanto Sunardi, Prof. Dr. ST, S.Si., M.Pd 76 suara dan 3) Gempur Santoso, Prof., Dr. Drs., M.Kes. 48 Suara. ( No. 249/Ad. 1/IX/2015, Laporan hasil Polling Bakal Calon Rektor ), sesuai Surat Keputusan PPLP PT PGRI Surabaya No. 186/PPL PT PGRI SBY/C/VI/2015 tentang Tata cara Pergantian Rektor Universitas PGRI Adi Buana Surabaya Masa Jabatan 2015-2019, pasal 6 Penetapan Rektor terpilih oleh Badan Penyelenggara, Badan penyelenggara berhak membuat putusan akhir tentang Rektor terpilih dan menerbitkan surat keputusan tersendiri berdasarkan ketentuan yang berlaku, jadi sesuai surat keputusan tersebut yang membuat putusan akhir Rektor terpilih adalah badan penyelenggara tersebut dengan berbagai pertimbangan yang terbaik. 
Umpan balik akademika UNIPA Surabaya terhadap Polling Rektor dianggap sebagai acara rutin empat tahunan, anggapan masyarakat kampus biasa-biasa saja tidak ada suatu hal yang menarik, ia datang tempat suara untuk memberikan suaranya tetapi hanya sebagai kewajiban sebagai anggota masyarakat Kampus untuk gugur wajib.

Dalam fenomena ini peneliti tertarik sekali untuk tertantang pada pertanyaan: “Bagaimana perilaku pemilih pada Polling Rektor UNIPA Surabaya tahun 2015!"

\section{Universitas PGRI Adi Buana} Surabaya membutuhkan legalitas dan dukungan dari Civitas akademika, sehingga dari awal mengetahui seberapa besar dukungan atau penolakan Civitas akademika terhadap kebijakan Universitas merupakan hal yang patut diketahui. Demikian juga bagi Civitas akademika adalah konsumennya maka mengetahui apa yang menjadi pemikiran dan perasaan Civitas Akademika terhadap produknya menjadi hal yang penting agar apa yang dihasilkan dan diluncurkan ke tengah Civitas akademika merespon dan diterima dengan baik oleh masyarakat.

\section{KAJIAN PUSTAKA}

Peneliti terdahulu oleh Amirudin, dkk dengan judul Jajak pendapat mencari sosok Rektor UNDIP yang tangguh, dalam polling rector di UNDIP mensyaratkan oleh panitia Rektor harus dari alumni UNDIP siapa pun orangnya, Rektor yang terpilih bisa membawa kampus yang menjanjikan dalam era otonomi kampus yang menjadi BHMN ( Badan Hukum Milik Negara), kampus menjadi tempat sampah bagi berbagai kejelekan dan kekeliruan yang dilakukan masyarakat, oleh karena itu kampus harus menjadi bengkel untuk mereparasi kejelekan dan kekeliruan. Urusan pemilihan Rektor tidak hanya menjadi urusan senat tetapi juga menjadi urusan semua civitas akademika, kesalahan memilih Rektor bukan saja menjadi masalah senat tetapi juga menjadi masalah semuanya. Namun sistem pemilihan Rektor hanya dilaksanakan oleh senat, maka bagaimana mendekatkan diri antara kehendak warga kampus dan senat, diperlukan jalan keluar.

Menurut Aminuddin, dkk (2002: 35) penelitian menghasilkan polling Rektor ini sifatnya public hearing dan sebaiknya hasil dari polling ini dapat dimanfaatkan sebagai dasar untuk menentukan cara pemilihan dan sosok yang relevan menjadi Rektor, berikutnya dengan adanya polling sebagai langkah awal untuk pemilihan Rektor, didapatkan tingkat polanya, maka di masa yang akan datang sebagai langkah untuk kajian-kajian lebih lanjut guna menentukan 
kebijakan untuk menentukan pemilihan Rektor periode mendatang.

Polling merupakan suatu kerja pengumpulan pendapat masyarakat umum dengan menggunakan teknik dan metode ilmiah. Metode yang digunakan untuk mengenali pendapat itu adalah survei yaitu suatu metode dimana objek adalah orang atau individu atau kelompok dan menggunakan kuisioner sebagai alat untuk mendapatkan data/informasi.

George Gallup dalam Fishkin (2005:5) polling sebagai instrumen yang serius dari reformasi demokrasi. Setiap warga negara memiliki peluang yang sama dipilih untuk berpartisipasi, dan rata-rata, lebih jauh mengulangi pengambilan sampel dari populasi yang sama. Menurut pendapat Gallup dalam Fishkin (2005:5) media dan polling bersama-sama akan memungkinkan orang untuk mendengar pendapat para pemimpin politik dan keduanya mendengar dan mengungkapkan mereka sendiri.

Menurut pendapat Giddens dalam Kacung (2012: 126) di samping terdapat fenomena dekratisasi yang meluas, Negara-negara yang sebelumnya otoriter berubah menjadi lebih demokratis, di Negara-negara yang demokrasi nya sudah mapan justru terdapat fenomena kekecewaan (disillusionment) terhadap demokrasi. Masyarakat menaruh harapan besar pada polling, justru masyarakat yang
Negara tergolong mapan dan maju dan demokratis banyak yang kecewa dari tindak lanjut dari hasil polling.

Karakteristik yang paling utama polling adalah berkaitan dengan publikasi hasil penelitian. Pertama, waktu penyelenggaraan dan publikasi terbatas. Jawaban seseorang adalah pada saat wawancara dilakukan.dan publikasi dilakukan ketika isu masih hangat. Bila wawancara dan publikasi di undur-undur maka isu usang, apabila polling tetap diadakan maka hasilnya tidak akan banyak membawa manfaat dan banyak ruginya.

Tahap permulaan dalam kegiatan polling adalah merancang polling, polling dirancang dengan memakai prinsip-prinsip ilmiah dalam metode penelitian sosial pertama, mengelompokkan tujuan polling. Hal penting dalam polling adalah menentukan dengan tepat tujuan polling yang akan dibuat. Tujuan yang diputuskan akan menentukan semua instrumen polling yang akan dipakai, populasi, bentuk informasi, waktu wawancara, dan metode wawancara.

Kedua, populasi dan sampel polling. Populasi polling ditentukan oleh topik dan tujuan yang akan dibuat. Misalnya kalau ingin mengetahui pendapat masyarakat terhadap pelaksanaan pemilihan Kepala Daerah maka populasinya adalah para pemilih Kepala Daerah. Sampel diambil dari populasi, apabila 
populasinya cukup besar.

Ketiga, memilih tipe informasi cara untuk mengetahui pendapat/perilaku adalah dengan bertanya, data tidak dapat diperoleh dengan observasi atau partisipasi tetapi menanyakan langsung kepada responden. Dengan daftar pertanyaan dibuat untuk menanyakan apa yang mereka rasakan atau yang mereka pikirkan terhadap isu- isu tertentu yang berkembang.

Keempat, memutuskan metode wawancara. Metode wawancara ditentukan sebelum polling dijalankan apakah memakai metode wawancara langsung, lewat surat atau wawancara lewat telepon.

Kelima, semua data/informasi tersedia terkumpul, langkah berikutnya adalah menganalisis data. Biasanya data di analisis berdasarkan prosentase kemudian disimpulkan dan di generalisasikan.

Menurut Herbert McClosky dalam Miriam (2014:367) partisipasi politik adalah kegiatan-kegiatan sukarela dari warga masyarakat melalui mana mereka mengambil bagian dalam proses pemilihan penguasa, dan secara langsung atau tidak langsung, dalam proses pembentukan kebijakan umum. Partisipasi masyarakat dalam keterlibatannya dalam proses politik dipengaruhi juga oleh perilaku masingmasing individu, atau kelompok dan masyarakat.

Perilaku masyarakat dalam kaitannya dengan partisipasi politik tidak hanya datang memberi suara dalam pemilihan umum melainkan partisipan aktif dalam kelompok kepentingan dan tindakan-tindakan yang bersifat politis, masyarakat yang berpartisipasi dalam proses politik, misalnya melalui pemberian suara atau kegiatan lain, terdorong oleh keyakinan bahwa melalui kegiatan bersama itu kepentingan mereka akan tersalur atau sekurang-kurangnya diperhatikan, dan bahwa mereka sedikit banyak dapat mempengaruhi tindakan dari mereka yang berwenang untuk membuat keputusan yang mengikat.

Teori pilihan publik adalah hasil dari interaksi politik di antara para pelaku rasional (diaplikasikan dalam konsep, seperti : keyakinan, preferensi, tindakan, pola perilaku serta kumpulan dan kelembagaan ) yang ingin memaksimalkan keuntungan bagi dirinya sendiri (Caparasso \& levine, 2008: 322).

Menurut pendapat Giddens (2000: 107) demokratisasi dalam konteks keluarga mengimplikasikan kesetaraan, saling menghormati, otonomi, pengambilan keputusan melalui komunikasi, dan kebebasan dari kekuasaan. Sehubungan dengan perilaku pemilih pembawaan demokratisasi yang berkembang sangat berpengaruh dalam menentukan 
pilihannya. Menurut pendapat Herbert McClosky, dalam Miriam (2014:370) partisipasi politik hanya terbatas pada kegiatan sukarela saja, yaitu kegiatan yang dilakukan tanpa paksaan atau tekanan siapa pun. Partisipasi hanya bersifat sukarela tidak ada unsur mobilisasi, ancaman, tekanan dari siapa pun.

$$
\text { Partisipasi politik. “Khamisi }
$$
(dalam Ruslan 200:46) memberi pengertian yang luas mengenai partisipasi politik bahwa partisipasi politik adalah hasrat seorang individu untuk mempunyai peran dalam kehidupan politik melalui keterlibatan administratif untuk menggunakan hak bersuara, melibatkan dirinya di berbagai organisasi, mendiskusikan berbagai persoalan politik dengan pihak lain, ikut serta melakukan berbagai aksi dan gerakan, bergabung dengan partai-partai atau organisasiorganisasi independent, ikut serta dalam kampanye penyadaran, memberikan penyadaran, memberikan pelayanan terhadap lingkungan dengan kemampuan sendiri.

Menurut Ostrogorki dalam Coleman (2011:170) alat lain yang memudahkan pertukaran dalam system social dan system politik ketika barter dua pihak tidak mungkin lagi adalah pihak perantara (intermediary) atau makelar. Cara kerja mesin politik di kota-kota Amerika pada pergantian abad itu sebagai sebuah pihak perantara. Bagi para pemilih mesin itu menyediakan uang dan pekerjaan sebagai penukar suara bagi anggota legislatif. Bagi anggota legislatif mesin tersebut menyalurkan suara dari para pemilih ditukar dengan pengesahan Legislatif yang menguntungkan dunia usaha. Bagi dunia usaha, mesin itu mendapatkan Legislatif yang menguntungkan ditukar dengan uang yang akan dipergunakan untuk membeli suara. Jadi antara pemilih dengan yang dipilih tidak berhubungan langsung melainkan menggunakan jasa makelar supaya barter terjadi.

Dalam memahami perilaku pemilih, penulis menggunakan pendekatan. yang dipakai penulis ada beberapa pendekatan, yaitu, pendekatan sosiologis, pendekatan psikologis, dan pendekatan ekonomis, pendekatan rasional, dan pendekatan domain kognitif uraian singkat mengenai pendekatan tersebut sebagai berikut:

Pendekatan sosiologis, perilaku memilih seseorang dipengaruhi oleh faktor- faktor lingkungan seperti sosial ekonomi, afiliasi etnis, tradisi keluarga, keanggotaan terhadap organisasi, usia, jenis kelamin, pekerjaan, tempat tinggal, dan lain-lain.

Pendekatan Psikologis, pendekatan psikologis yang awalnya dikembangkan di Amerika Serikat memusatkan pada tiga aspek, yakni 
keterikatan seseorang dengan partai politik, orientasi seseorang kepada calon presiden maupun anggota parlemen, dan orientasi seseorang terhadap isu-isu politik.

Pendekatan

Ekonomis, pendekatan ini sering disebut pula sebagai pendekatan rasional. Perilaku pemilih terhadap partai politik tertentu berdasarkan perhitungan, tentang apa yang diperoleh bila seseorang menentukan pilihannya, baik terhadap calon presiden maupun anggota parlemen.

Pendekatan rasional, Pendekatan ini sebenarnya tidak berbeda dengan pendekatan ekonomis namun menambahkan beberapa penelitian dan penjelasan. Pendekatan rasional yang dimaksud berkaitan dengan orientasi utama pemilih, yakni orientasi isu dan orientasi kandidat. Perilaku pemilih berorientasi isu berpusat pada pertanyaan: apa yang seharusnya dilakukan oleh pemerintah dari partai yang berkuasa kelak dalam memecahkan persoalan-persoalan yang sedang dihadapi masyarakat, bangsa, dan negara.

Pendekatan domain kognitif (pendekatan marketing), mengembangkan model perilaku pemilih berdasarkan beberapa domain yang terkait dengan marketing. Dalam pengembangan model tersebut, mereka menggunakan sejumlah kepercayaan kognitif yang berasal dari berbagai sumber seperti pemilih, komunikasi dari mulut ke mulut, dan media massa

\section{METODE PENELITIAN}

A. Jenis Penelitian

Jenis ini akan memaparkan tentang bagaimana partisipasi akademika Universitas PGRI Adi Buana Surabaya dalam Polling Rektor tahun 2015. Metode yang digunakan adalah metode penelitian deskriptif dengan pendekatan kualitatif menguji konsteks secara keseluruhan.

B. Sumber Data

Secara rinci metode yang digunakan meliputi tahapan-tahapan penelitian adapun sumber data dalam penelitian adalah subjek dari mana data dapat diperoleh. Adapun sumber data penelitian ini dibagi menjadi 2(dua), yaitu:

1) Data primer merupakan data yang didapat dari sumber pertama.

Peneliti mengumpulkan data primer dari jawaban Dosen dan Fungsionaris senat mahasiswa Universitas PGRI Adi Buana Surabaya atas pertanyaan yang diajukan dalam kuesioner.

2) Data sekunder merupakan data primer yang telah diolah lebih lanjut.

Data sekunder merupakan data atau informasi yang telah dikumpulkan oleh orang-orang yang berkaitan dengan pelaksanaan Polling Rektor, para Pimpinan Academika, Panitia Ad Hoc Polling Rektor dan para pemilih, yang berhubungan dengan masalah 
penelitian, seperti rekapitulasi jumlah pemilih, dan jumlah responden. Hal ini sejalan sesuai dengan apa yang dikemukakan oleh ahli Moleong (2000:1) yaitu prosedur pendekatan kualitatif menghasilkan data-data deskriptif berupa kata-kata tertulis atau lisan dari perilaku yang diamati.

Lokasi penelitian terletak di dua kampus pertama di Kampus Universitas PGRI Adi Buana Surabaya Jl. Ngagel dadi IIIB/37 Surabaya dan kampus kedua Universitas PGRI Adi Buana Surabaya Jl. Dukuh Menanggal XII Surabaya

Metode penelitian ini menggunakan metode kualitatif dengan pendekatan yang digunakan, melibatkan wawancara mendalam setengah berstruktur, observasi partisipasi dan analisis tekstual. Suatu proses penelitian sepintas ( RAP, rapid assessment proses) akan di terapkan dalam memilih situs program. Suatu pendekatan kerja sama dalam menyusun tim penelitian akan diusahakan, dengan partisipasi dari pejabat Panitia ad Hoc Polling Rektor, dan orang-orang yang mempunyai hak pilih. Untuk memilih informan yang benar-benar relevan dan kompeten sesuai masalah penelitian dengan harapan data yang diperoleh dapat digunakan untuk membangun teori.

c. Metode Pengumpulan Data

Proses pengumpulan data, data diperoleh dari sumber data yang bisa dipercaya dengan teknik pengumpulan data (1) wawancara mendalam (Indeep interviewing), (2) observasi atau pengamatan berperan serta (participant observation), dan (3) studi dokumentasi. Ketiga teknik pengumpulan data tersebut merupakan teknik dasar yang digunakan dalam penelitian kualitatif. Secara lebih rinci, metode-metode yang akan digunakan adalah:

1. Penggunaan sumber sekedar. Data dari Universitas PGRI Adi Buana Surabaya (Bagian Kepegawaian, Perkumpulan Perguruan Tinggi PGRI Surabaya) dan dari terbitanterbitan ilmiah/nonfiksi (etnografi, sosiologi, sejarah) maupun fiksi (termasuk yang popular) serta cacatan atau arsip yang tidak diterbitkan pada lembaga-lembaga penelitian setempat.

2. Pengamatan etnografis. Bukan saja observasi visual, tetapi juga interaksi verbal antara peneliti dan berbagai individu yang hadir di berbagai setting. Wawancara informal bisa membuahkan beraneka ragam data yang amat penting, yang acapkali tidak bisa terencana secara sistematis pertanyaan-pertanyaannya. Peneliti harus senantiasa pasang kuping agar sesuatu yang tidak diperkirakan juga terekam. Semua hasil observasi dicatat dalam kerangka-kerangka yang telah 
ditentukan (walaupun secara fleksibel).

3. Kelompok fokus (fokus group). FGD (fokus group discussion) berguna dalam merancang hipotesis dan menjelaskan atau menafsirkan temuan-temuan penelitian survey. Dalam FGD acapkali hal-hal yang tidak dapat muncul karena sifat hubungan peneliti dengan yang diteliti tidak dimungkinkannya.

Dalam kelompok yang cenderung homogen, dengan fasilitas seperlunya, data semacam itu dapat muncul.

4. Wawancara mendalam (in-depth). Wawancara semacam ini dilakukan dengan informan kunci (key informants) yang bisa dipercaya dan subjek penelitian pada umumnya. Informasi kunci adalah orang-orang yang karena pengetahuannya yang luas mendalam, dan mempunyai pendidikan yang tinggi maupun pendidikan yang rendah, dan orang yang berpenghasilan yang besar, orang yang mempunyai penghasilan yang kurang dapat memberikan data yang berharga.

d. Metode Penentuan Informan

Analisis informasi, ada tiga tahapan yang akan dilakukan dalam menganalisis data dalam penelitian, yaitu reduksi data, penyajian data, dan penarikan kesimpulan/verifikasi, Miles dan Huberman dalam Imron Arifin (2011: 39). Secara rinci langkah-langkah yang dilakukan adalah proses pelacakan dan pengaturan secara sistematis transkrip wawancara, cacatan lapangan, dan bahan lain yang dikumpulkan untuk meningkatkan pemahaman terhadap bahan-bahan tersebut agar dapat di-presentasikan kepada orang lain sesuai dengan fokus penelitian.

e. Metode Analisis Data

Secara teknis yang dilakukan peneliti dalam menganalisis setelah pengumpulan data, yaitu mengembangkan sistem pengkodean (2) penyotiran data. Analisis dilakukan dengan mengembangkan sistem pengkodean. Agar keabsahan data dalam penelitian kualitatif ini betulbetul baik dan dipercaya, maka dilakukan pengecekan keabsahan data yang didasarkan pada criteria tertentu sebagaimana yang disarankan Lincoln \& Guba (1995) yaitu kredibilitas (kepercayaan) transferabilitas (keteralihan), dependebilitas (ketergantungan), konfirmabilitas (kepastian).

\section{HASIL DAN PEMBAHASAN}

Hasil penelitian berdasarkan wawancara dari beberapa informan yang mewakili kelompoknya dengan rumusan masalah tentang Bagaimana perilaku pemilih dalam mensikapi citra 
masing-masing kandidat dalam Polling Rektor UNIPA Surabaya Tahun 2015 sebagai berikut :

Wawancara dengan para pemilih Polling Rektor Tahun 2015, dengan RDHY berpartisipasi dalam Polling rektor mulai massa Kampanye dengan pemasangan Foto masing-masing kandidat Bakal Calon Rektor, kami sudah mengikuti dan memantau langsung, terutama pada citra dari masing-masing ketiga Calon Bakal Rektor, dari ketiga bakal calon Rektor, saya tanyakan pada orang-orang yang mengenal betul latar belakang dan prestasi masing-masing bakal Calon Rektor UNIPA Surabaya, baik Bapak Djoko Adi Walujo, Bapak Gempur Santoso dan Bapak Hartanto Sunardi, jadi pada waktu hari pemilihan Polling Rektor nanti pilihan saya jatuh pada salah satu dari ketiga Bakal Calon Rektor Adi Buana Surabaya, sesuai dengan hati nurani tanpa paksaan dari orang lain, menurut saya akan membawa perubahan UNIPA Surabaya dengan dipimpin oleh Bakal calon yang saya pilih akan berubah bertambah baik dan semakin baik, setelah saya pikir-pikir dan saya timang- timang pilihan saya jatuh pada tidak memilih, dengan pertimbangan citra dari masing-masing ketiga bakal calon Rektor belum sesuai dengan harapan saya.

Berikutnya hasil wawancara dengan informan DW yang berkaitan dengan bagaimana perilaku pemilih dalam mensikapi efektivitas Visi dan misi masing- masing kandidat dalam Polling Rektor UNIPA Surabaya Tahun 2015, dari hasil wawancara yang mendalam yang kami peroleh data adalah bahwa pemilih calon bakal rektor memilih dan tidak memilih, itu tergantung pada Visi dan misi dari masing-masing kandidat bakal calon rektor, apakah Visi dan misi rektor nanti apa betul-betul membawa perubahan perlu dikaji secara mendalam, jangan-jangan hanya slogan saja, fakta pengalaman nya kalau terpilih tidak terjadi perubahan sesuai dengan harapan dari Civitas Academika Universitas PGRI Adi Buana Surabaya, saya berharap dengan visi dan misi dari masing-masing ketiga Bakal Calon Rektor Universitas PGRI Adi Buana Surabaya, baik dari Visi dan misi baik dari Bapak Joko Adi Waludjo, bapak Gempur Santoso dan bapak Hartanto Sunardi, saya dapat mencermati dan bisa menentukan pilihan saya, baik jatuhnya memilih dan tidak memilih, tergantung pada pertimbangan terakhir kalau betulbetul visi dan misi dari masing-masing ketiga Calon Bakal Rektor UNIPA Surabaya, dan harus memilih salah satu pilihan saya, yang pasti yang saya pilih salah satu dari ketiga calon bakal rektor dengan visi dan misinya dapat membawa perubahan Universitas PGRI Adi Buana ke depan bertambah baik 
dan semakin baik, setelah saya pikirpikir dan saya timang-timang dan saya kaji visi dan misi dari masing-masing ketiga bakal calon rektor, pilih saya jatuh pada tidak memilih pada ketiga calon bakal Rektor dengan pertimbangan visi dan misi dari beliau belum mengena dan belum akan bisa membawa perubahan UNIPA Surabaya akan lebih baik, lebih baik dan dengan pertimbangan lain kedua bakal calon rektor yang lain visi dan misinya juga baik tetapi belum bisa membawa perubahan dan keduanya umurnya juga sudah sepuh.

Berikutnya hasil wawancara dengan informan MSY bagaimana perilaku pemilih dalam mensikapi pesan perihal menyentuh akar permasalahan yang disampaikan masing-masing kandidat dalam Polling Rektor UNIPA Surabaya Tahun 2015, menurut pendapat kami dari masingmasing ketiga bakal calon Rektor, yang bisa menyentuh akar permasalahan, cara menghadapi dengan cepat, efisien dan pas pada sasaran dari masingmasing bakal calon rector UNIPA Surabaya, adalah Bapak Djoko Adi Walujo, jika dibandingkan dari kedua masing-masing bakal calon Rektor Adi buana Surabaya, beliau sudah sangat berpengalaman dalam menangani permasalahan organisasi, baik di Universitas PGRI Adi Buana sendiri maupun organisasi-organisasi di luar UNIPA Surabaya, dan kedua bakal
Calon Rektor yang yang lain pengalamannya belum sampai di sana, jadi untuk menangani permasalahan yang sangat mendesak dan darurat masih diragukan. Setelah kami pikirpikir dan menimbang- nimbang pilihan kami pada polling rector jatuh pada Bapak Djoko Adi Walujo, dengan pertimbangan dari segi pengalaman beliau juga sangat berpengalaman dalam berorganisasi, bila ada permasalahan di kampus tercinta di UNIPA Surabaya, tidak menunggu laporan beliau langsung tanggap dan bergerak untuk mengatasi permasalahan, dan dalam perencanaan kegiatan beliau mempersiapkan sangat matang tidak spontanitas.

\section{SIMPULAN}

Perilaku pemilih sangat dipengaruhi citra masing-masing kandidat dalam Polling Rektor UNIPA Surabaya Tahun 2015. Perilaku pemilih memperhatikan dan mensikapi efektivitas Visi dan misi masing-masing kandidat dalam Polling Rektor UNIPA Surabaya Tahun 2015. Perilaku pemilih sangat mensikapi pesan perihal menyelesaikan permasalahan yang disampaikan masing-masing kandidat dalam Polling Rektor UNIPA Surabaya Tahun 2015.

\section{DAFTAR PUSTAKA}

Aminudin, dkk. 2002. Jajak Pendapat mencari sosok Rektor UNDIP yang 
Tangguh. Semarang: Universitas Diponegoro.

Budiardjo, Miriam. 2014. Dasar-dasar ilmu politik. Jakarta : Gramedia.

Coleman, James S. 2011. Dasar-dasar teori social : foundations of social theory. Bandung: Nusa Media

Duverger, Maurice. 2013. Sosiologi

Politik. Jakarta: Rajawali Pers.

Fishkin, James S. and Robert C Luskin. 2005. Experimenting with a democratic ideal: deliberative polling and opinion. Stanford:

Departemen of goverment

Giddens, Anthony. 2000.Thte Third Way : Jalan ketiga Pembaharuan Demokrasi Sosial. Jakarta: Gramedia.

Giddens, Anthony. 2003. The Constitution of society : Teori Strukturasi untuk analisis social. Pasuruan: Pedati

http://jokobando.tripod.com/index files Lstatistik per.htm. diunduh tanggal. 13 Pebruari - 2016

Maram, Rafael Raga. 2013. Pengantar Sosiologi Politik. Jakarta: Rineka Cipta Marijan,

Kacung. 2012. Sistem politik Indonesia : konsolidasi pasca orde baru.Jakarta: Kencana.

Mufti, Muslim. 2013. Teori-Teori Demokrasi. Bandung: Pustaka Setia.

Mahfud MD, Moh. 2014. Politik Hukum di Indonesia. Jakarta: Rajawali Pers.
Moleong, L.J. 2000. Metodologi Penelitian Kualitatif. Bandung: Remaja Roskakarya.

Ritonga, Irwan Taufiq. 2010. Apakah Incumbent memanfaatkan Anggaran Pendapatan dan Belanja daerah (APBD) Untuk Mencalonkan Kembali dalam Pemilihan umum Kepala Daerah (PEMILUKADA). Simposium Nasional Akuntansi XIII.Purwokerto : Univ. Jendral Sudirman

Riyanto, E. Armada. 2014. Berfilsafat Politik. Yogyakarta: Kanisius.

Sukarna. 1979. Sistem Politik. Bandung: Alumni. 